\title{
Settlement of India/EU WTO Dispute re Seizures of In-Transit Medicines: Why the Proposed EU Border Regulation Isn't Good Enough
}

\author{
Brook K. Baker \\ Northeastern University School of Law, b.baker@neu.edu
}

Follow this and additional works at: https://digitalcommons.wcl.american.edu/research

Part of the Intellectual Property Law Commons, and the International Trade Law Commons

\section{Recommended Citation}

Baker, Brook K. 2012. Settlement of India/EU WTO Dispute re Seizures of In-Transit Medicines: Why the Proposed EU Border Regulation Isn't Good Enough. PIJIP Research Paper no. 2012-02 American University Washington College of Law, Washington, D.C.

This Article is brought to you for free and open access by the Program on Information Justice and Intellectual Property and Technology, Law, \& Security Program at Digital Commons @ American University Washington College of Law. It has been accepted for inclusion in Joint PIJIP/TLS Research Paper Series by an authorized administrator of Digital Commons @ American University Washington College of Law. For more information, please contact DCRepository@wcl.american.edu. 


\title{
SETTLEMENT OF INDIA/EU WTO DiSPUTE RE SEIZURES OF IN-TRANSIT MEDICINES: WHY THE PROPOSED EU BORDER REGULATION ISN'T GOOD ENOUGH
}

\author{
Professor Brook K. Baker ${ }^{1}$
}

\begin{abstract}
European Customs officials have used fictive patent rights to justify the seizure of lawful generic medicines produced in India and destined for nonEuropean markets. Following a public outcry and initiation of two WTO complaints, the EU has proposed amendments to Border Regulations Measure 1383/2003. The Proposed Border Regulation in its current form will not adequately resolve the risk of interception in Europe of medicines lawfully manufactured and exported from India and destined for lawful import and consumption in a non-EU country. This analysis concludes that multiple weaknesses remain in the Border Regulations, including: (1) continued coverage of alleged patent and supplemental protection certificate infringement claims that can be based on fictional patent status under national law; the addition of utility models; and continued coverage of design rights and civil trademark infringement matters that are more appropriately addressed in ordinary court proceedings; (2) inappropriate application of the law of the in-transit country instead of the law of the importing country when assessing an IP infringement claim; (3) unclear directives to "consider" the risk of diversion to EU markets with no explicit prohibition against seizing in-transit medicines in the absence of such a showing and without requirement of clear and convincing evidence of an imminent diversion by an identified party; (4) insufficient opportunities to be heard for declarants and holders of goods; and (5) insufficient remedies for declarants and holders of goods and for purchasers and consumers who are proximately harmed by unsuccessful border applications.
\end{abstract}

\footnotetext{
${ }^{1}$ Professor Northeastern U. School of Law, Affiliated with its Program on Human Rights and the Global Economy; Honorary Research Fellow, University of Kwazulu Natal, Faculty of Law, S. Africa; Policy Analyst Health GAP (Global Access Project)
} 


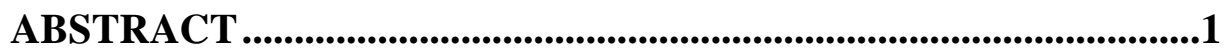

I. INTRODUCTION ..............................................................

II. BRIEF BACKGROUND TO THE PROPOSED REGULATION................5

III. CRITIQUE OF THE PROPOSED REGULATION -

BETTER IS Not GoOD ENOUGH ............................................9

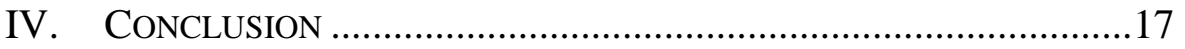

\section{INTRODUCTION}

On July 28, 2011, the Ministry of Commerce and Industry of the Government of India announced an "Understanding" in principle with the European Union (EU) concerning a pending World Trade Organization (WTO) complaint challenging EU customs measures that had been used to justify seizures of Indian generic medicines in transit through Europe to destinations in Latin America, Oceania, and Africa. ${ }^{2}$ These seizures and the EU's delayed and defensive response ${ }^{3}$ to early and repeated expressions of diplomatic and human rights concerns ${ }^{4}$ prompted India and Brazil to initiate dispute resolution procedures - namely preliminary requests for

${ }^{2}$ Press Release, Government of India Ministry of Commerce and Industry, Indian EU Reach an Understanding on Issue of Seizure of Indian Generic Drugs in Transit (July 28, 2011), available at http://pib.nic.in/newsite/erelease.aspx?relid=73554.

${ }^{3}$ See WTO General Council, Minutes of Meeting, WT/ GC/M/118 (Feb. 3, 2009), available at http://docsonline.wto.org/GEN_highLightParent.asp?qu=\&doc=D\%3A\%2FDDFDOCUM ENTS\%2FT\%2FWT\%2FGC\%2FM118.DOC.HTM . (arguing that BMR was fully TRIPScompliant and that Europe was acting benevolently to prevent trade in "counterfeit" medicines that were a risk to public health in developing countries).

${ }^{4}$ See, e.g., Intervention by India, Agenda Item ' $M$ '- Other Business - Public Health dimension of the TRIPS Agreement (Feb. 4, 2009), available at http://www.ipwatch.org/weblog/wp-content/uploads/2009/03/intervention-by-india.doc; Statement by Brazil, TRIPS Council Agenda Item M (Other Business), Public Health Dimension of the TRIPS Agreement, (Feb. 4, 2009), available at http://keionline.org/blogs/2009/03/04/brazilian-intervention-at-trips-council; Letter from various NGOs to the Director Generals of the WHO and the WTO Feb. 18, 2009, available at http://keionline.org/misc-docs/seizures/WHO_seizures_18feb.pdf; UNITAID Statement on Dutch Confiscation of Medicines Shipment, available at http://www.unitaid.eu/en/resources/news/156-unitaid-statement-on-dutch-confiscation-ofmedicines-shipment.html; World Health Organization [WHO], Statement-Access to Medicines (March 13, 2009), available at http://www.who.int/mediacentre/news/statements/2009/access-medicines20090313/en/index.html. 
consultations - against the EU at the World Trade Organization. ${ }^{5}$

Pursuant to the announced Understanding, the European Union will no longer intercept in-transit generic medicines unless there is adequate evidence to satisfy customs authorities that there is a substantial likelihood of diversion of such medicines to the EU market. In addition, the EU is to issue interim guidelines advising member countries how border enforcement should be done. Finally, the EU has proposed a new Regulation (Proposed Border Regulation) ${ }^{6}$ to replace challenged Council Regulation (EC) No. 1383/2003, the so-called Border Measures Regulation (BMR 1383/2003). ${ }^{7}$ Although India does not completely endorse the phrasing of the draft proposal, India will convey its views on the proposal to EU during the expected 12-18 month approval process. ${ }^{8}$ There are reports that India does not consider the draft strong enough to satisfy its requirements. ${ }^{9}$

In exchange for these undertakings and as long as they are adhered to,

\footnotetext{
${ }^{5}$ Request for Consultations by India, European Union - Seizure of Generic Drugs in Transit, WT/DS408 (May 11, 2011), available at http://www.wto.org/english/tratop_e/dispu_e/cases_e/ds408_e.htm; Request for Consultations by Brazil, European Union - Seizure of Generic Drugs in Transit, WT/DS409, available at http://www.wto.org/english/tratop_e/dispu_e/cases_e/ds409_e.htm. The consultations were protracted and included premature claims of settlement. See generally Consultations on WTO Drug Transit Case Continue, Intellectual Property Watch, Sept. 16, 2010, available at $\mathrm{http} / / / \mathrm{www}$.ip-watch.org/weblog/2010/09/16/consultations-on-wto-case-ondrugs-in-transit-continue/; C.H. Unnikrishan, India may move WTO as it seeks to resolve EU dispute, livemint.com\&WSJ (Oct. 10, 2010), http://www.livemint.com/2010/10/11225420/India-may-move-WTO-as-it-seeks.html; Kaitlin Marla, Minister, India Anticipates European Fix to Law Delaying Generic Shipments, IP-WATCH (Oct. 20, 2010), available at http://www.ipwatch.org/weblog/2010/10/20/ambassador-india-anticipates-european-fix-to-law-delayinggenerics-shipments/.

${ }^{6}$ Proposal for a Regulation of the European Parliament and of the Council Concerning Customs Enforcement of Intellectual Property Rights, COM(2011) 285 final (May 25, 2011), [hereinafter Proposed Border Regulation], available at

http://ec.europa.eu/taxation_customs/resources/documents/customs/customs_controls/ counterfeit_piracy/legislation/com285_en.pdf.

${ }^{7}$ Council Regulation 1383/2003, 2003 O.J. (L 196/7), available at http://eurlex.europa.eu/LexUriServ/LexUriServ.do?uri=OJ:L:2003:196:0007:0014:EN:PDF.

${ }^{8}$ Asit Ranjan Mishra, Generic drugs seizure row: India, EU Reach 'Interim Settlement, ' livemint.com\&WSJ (July 29, 2011), http://www.livemint.com/articles/2011/07/28221918/Generic-drugs-seizure-rowInd.html? atype $=$ tp.

${ }^{9}$ Matthias Williams, Update 2-India, EU Health Drugs Seizures Dispute with Interim Agreement, REUTERS (July 28, 2011), http://www.reuters.com/article/2011/07/28/india-eudrugs-idUSL3E7IS4WW20110728.
} 
India has assured the EU that it will not request the establishment of a dispute settlement panel at the WTO. However, India retains the option to revive the dispute if the EU does not abide by the core principles agreed to in the Understanding. ${ }^{10}$ This Understanding between the EU and India does not directly impact the parallel WTO dispute filed by Brazil, but as a practical matter, Brazil's dispute is likely to be suspended pending final enactment of the new Regulation.

The question arises whether India is correct that the Proposed Border Regulation in its current form will not adequately resolve the risk of interception in Europe of medicines lawfully manufactured and exported from India and destined for lawful import and consumption in a non-EU country. This analysis concludes that multiple weaknesses remain, including:

1. continued coverage of alleged patent and supplemental protection certificate infringement claims that can be based on fictional patent status under national law; the addition of utility models; and continued coverage of design rights and civil trademark infringement matters that are more appropriately addressed in ordinary court proceedings;

2. inappropriate application of the law of the in-transit country instead of the law of the importing country when assessing an IP infringement claim;

3. directives to "consider" the risk of diversion to EU markets with no explicit prohibition against seizing in-transit medicines in the absence of such a showing and without requirement of clear and convincing evidence of an imminent diversion by an identified party;

4. insufficient opportunities to be heard for declarants and holders of goods; and

5. insufficient remedies for declarants and holders of goods and for purchasers and consumers who are proximately harmed by unsuccessful border applications.

Unless these public health weaknesses are addressed, India's WTO complaint should not be withdrawn. Moreover, the Proposed Border

${ }^{10}$ EU Agrees to Stop Confiscation of India Generic Drugs, THE ECONOMIC TIMES (July 29, 2011), http://articles.economictimes.indiatimes.com/2011-07-

29/news/29829346_1_customs-regulations-indian-generic-drugs-international-intellectualproperty-agreement. 
Regulation should be rejected by the European Council in its present form.

\section{BRIEF BACKGROUND TO THE PROPOSED REGULATION}

Between 2008 and 2009 Dutch, and on one occasion German, customs officials detained nearly 20 shipments of generic medicines ${ }^{11}$ under the authority of BMR 1383/2003. When interpreting BMR 1383/2003, Dutch customs authorities applied the judicially created rule that the IP status of in-transit medicines should be judged under the fiction that the medicines had been manufactured in the Netherlands. ${ }^{12}$ This interpretation was based at least in part on recital no. 8 of BMR 1383/2003 which reads "Proceedings initiated to determine whether an intellectual property right has been infringed under national law will be conducted with reference to the criteria used to establish whether goods produced in that Member State infringe intellectual property rights." (Emphasis added.) In some circumstances, customs officials acted ex officio to initiate temporary seizures based on suspicion of domestic patent law violation under the manufacturing fiction. However, they continued such seizures based on applications by Big Pharma, which requested impounding and delaying shipments of life-saving medicines bound from India, where they had been lawfully manufactured and exported, to countries in Africa, Oceania, and Latin America, where they would have been lawfully imported, marketed and consumed. ${ }^{13}$ Most of the medicines were seized on the basis of

${ }^{11}$ John Miller \& Geeta Anand, India Prepares EU Trade Complaint, WALL ST. J. (August 6, 2009), available at http://online.wsj.com/article/SB124949598103308449.html?mod=3Dgooglenews_wsj.

${ }^{12}$ Rechtbanks-Gravenhage [District Court in The Hague], 18 juli 2008, IER 2008, 83 m.nt. J.G. Kuhlmann (Sosecal v. Sisvel) (Neth.), ), available at http://www.eplawpatentblog.com/PDF_December09/The\%20Hague\%20DC\%20Sisvel\%20 v\%20Sosecal\%20EN.pdf ; see Frederick J. Abbott, Seizures of Generic Pharmaceuticals in Transit Based on Allegations of Patent Infringement: A Threat to International Trade, Development and Public Welfare, 1 W.I.P.O.J. 43, 47 (2009), available at http://www.wipo.int/about-wipo/en/wipo_journal/pdf/wipo_journal_1_1.pdf; Frank Eijsvogels, Sisvel v. Sosecal: Acting Against Transit Goods StiLl Possible Under THE ANTI PIRACY REGULATION IN THE NETHERLANDS, IP Intelligence Eur. 10 (Howrey L.L.P., Amsterdam, Netherlands), 2008.

${ }^{13}$ E.g., Letter from Merck and Du Pont lawyers to Dr. Reddy's Laboratory, Inc. (December 24, 2008 ), available at http://online.wsj.com/public/resources/documents/eudrugs2009letter1.pdf (stating "the Court in the Netherlands has determined that products in transit qualify as products infringing intellectual property rights where this would have been the case if the goods would have been manufactured in the Netherlands); Letter sent by Eli Lilly lawyers to Cipla (December 09, 2008), available at 
fictional patent violations, but in at least one other instance, generic medicines were seized by over-zealous German customs officials on the premise that the generic medicine, "amoxicillin," which as required bore the international non-proprietary name, had a "brand" confusingly similar to GlaxoSmithKline's trademark protected medicine "Amoxil.". 14 After these multiple seizures, customs authorities required that the suspect medicines be destroyed, returned to India, or on occasion onward shipped on a delayed basis to their ultimate destination. ${ }^{15}$

Leading European scholars opined that it was unlawful under European Council law to apply BMR 1383/2003 to truly in-transit medicines medicines not destined for or likely to be diverted to European Markets. ${ }^{16}$ The application of fictional IP patent and trademark rights to medicines-intransit was also roundly criticized by these same scholars ${ }^{17}$ and by India $^{18}$ for violating core principles of the Agreement on Trade-Related Aspects of Intellectual Property Rights (TRIPS or TRIPS Agreement), ${ }^{19}$ including Articles 2, 28, 31, 41, 42, and 52, Articles V and $\mathrm{X}$ of the General

http://online.wsj.com/public/resources/documents/eudrugs2009letter3.pdf (concerning Olanzapine en route from India to Peru).

${ }^{14}$ European Generic Drug Seizures Take Centre Stage at TRIPS Council Meeting, 13 BRIDGES WEEKLY TRADE NEWS DIGEST (June 10, 2009), available at http://ictsd.org/i/news/bridgesweekly/48330/.

${ }^{15}$ Press Release, supra note 2.

${ }^{16}$ See, e.g., Henning Grosse Ruse-Khan \& Thomas Jaeger, Policing Patents Worldwide? EC Border Measures against Transiting Generic Drugs under EC-and WTO Intellectual Property Regimes, 40 INT'L REV. InTELL. PROP. \& COMPETITION L. 502 (2009); contra Xavier Seuba, Free Trade of Pharmaceutical Products: The Limits of Intellectual Property Enforcement at the Border, InT'L CENTRE FOR TRADE \& SUSTAINABLE DEV. (2010), available at http://ictsd.org/downloads/2011/12/free-trade-of-pharmaceuticalproducts.pdf.

${ }^{17}$ Ruse-Khan \& Jaeger, supra note 16; Seuba, supra note 16. Ruse-Khan and Jaeger have been the most vociferous in arguing that Article 10 of BMR authorizing seizure goods in transit based on alleged IP infringement under of the domestic law of the transit country may run counter to Article 52 of TRIPS which requires that border measures be applied based on the "law of the country of importation."

${ }^{18}$ India WTO Complaint, supra note 3. India's comprehensive WTO complaint cited violations of Paragraphs 2, 3, 4, and 7 of Article V and Article X of the GATT 1994 (unreasonable and discriminatory interference of legitimate trade using routes most convenient for international transit); and Articles 2, 28, 31, 41 and 42 of the TRIPS Agreement, especially in reference to the Doha Declaration and the August 6 Decision (unreasonable interference with freedom of transit of generic medicines resulting in unnecessary burdens and unwarranted delays and frustrating export of medicines lawfully produced to countries where they could be lawfully consumed).

${ }^{19}$ Marrakesh Agreement Establishing the World Trade Organization, art. 8(1), annex 1C, Apr. 15, 1994, 1867 U.N.T.S. 154, available at http://www.wto.org/english/docs_e/legal_e/27-trips.pdf. 
Agreement on Tariffs and Trade, the Doha Declaration on the TRIPS Agreement and Public Health, ${ }^{20}$ and the Decision of 30 August 30 on Paragraph 6 of the Doha Declaration. ${ }^{21}$ At a more fundamental level, legal scholars criticized BMR 1383/2003 and the EU's multiple seizures of generic medicines for violating core features of the international order including: (a) the territoriality of IP rights, ${ }^{22}$ (b) respect for the sovereign "independence" of countries to adopt and implement TRIPS-compliant patent regimes as they consider appropriate, ${ }^{23}$ (c) freedom of transit of goods moving through a country's transportation systems in the stream of international trade, ${ }^{24}$ and (d) the human right to health and of access to essential medicines. ${ }^{25}$

These issues were placed squarely before the European Court of Justice in two joined cases, C-446/09 and C-495/09 Philips/Nokia ${ }^{26}$ adjudicating the legality of border actions by customs agents detaining IP-suspect goods, temporarily warehoused or placed in external transit procedures, based on mere suspicion of diversion and/or reliance on the manufacturing fiction. On December 1, 2011, the European Court of Justice issued an opinion ${ }^{27}$ ruling that goods in customs suspensive procedures, including warehousing and external transit, that are suspected of violating trademark, copyright,

${ }^{20}$ Declaration on the TRIPS Agreement and Public Health, Ministerial Conference, Fourth Session, Doha, Nov. 9-14 2001, WT/MIN(01)/DEC/1 (Nov 142001), available at http://www.wto.org/english/thewto_e/minist_e/min01_e/mindecl_e.htm.

${ }^{21}$ Decision of the General Council of Aug. 30, 2003, Implementation of Paragraph 6 of the Doha Declaration on the TRIPS Agreement and Public Health, WT/L/540 (Sept. 1, 2003), available at http://www.wto.org/english/tratop_e/trips_e/implem_para6_e.htm.

${ }^{22}$ Seuba, supra note 16, at 16-17; Ruse-Khan \& Jaeger, supra note 16, at 518-519; Abbott, supra note 12, at 44-45. The territoriality criticism is based on the premise that IPrelated acts done outside a nation's territory do not violate the territorial rights in force within national borders and that medicines temporarily in-transit do not involve any prohibited "use" of the patent (making, using, offering for sale, selling, or importing for these purposes) within a country's territorial market.

${ }^{23}$ Seuba, supra note 16, at 16-17; Ruse-Khan \& Jaeger, supra note 16, at 521-524; Abbott, supra note 12, at 44.

${ }^{24}$ Seuba, supra note 16, at 9-10; Ruse-Khan \& Jaeger, supra note 16, at 532-536; Abbott, supra note 12, at 45-46.

${ }^{25}$ Seuba, supra note 16, at 22-23; Ruse-Khan \& Jaeger, supra note 16, at 529-532.

${ }^{26}$ Case C-446/09, Koninklijke Philips Electronic (2010) OJ C 24/29, (relating to the old, superseded Customs Regulation No. 3295/94); and Case C-446/09, Nokia Corporation (2010) OJ C 37/22 (relating to BMR 1383/2003).

27 Joined Cases C-446/09 \& C-495/09, Koninklijke Philips Electronics NV v. Lucheng Meijing Indus. Co., Nokia Corp. v. Her Majesty's Comm'rs of Revenue and Customs, 2011 E.C.R. *** [hereinafter Philips/Nokia Judgment], available at http://curia.europa.eu/juris/document/document.jsf?text=\&docid=115783\&pageIndex=0\&d oclang=en $\&$ mode $=$ req $\&$ dir $=\&$ occ $=$ first $\&$ part $=1 \&$ cid $=2701$. 
and design rights under EU Member State law: (1) could not even be temporarily detained in the absence of evidence that the goods had been sold, offered for sale or advertised in the EU or that there were other indications that operators are about to direct the goods towards European Union consumers or were otherwise disguising their commercial intentions; and (2) could not be considered abandoned or destroyed unless a substantive examination has proven that the challenged goods have been sold, offered for sale or advertised to EU consumers or that there is documentation showing that diversion is envisaged. ${ }^{28}$ Temporary detention requires a showing, "based on the facts of the case" 29 of a planned or advertised sale or a lack of clarity about the intended destination of the goods, the identity of the manufacturer or consignee, or a failure to

${ }^{28} I d$. at 9779 contains the ruling of the Court:

Council Regulation (EC) No 3295/94 of 22 December 1994 laying down measures concerning the entry into the Community and the export and re-export from the Community of goods infringing certain intellectual property rights, as amended by Council Regulation (EC) No 241/1999 of 25 January 1999, and Council Regulation (EC) No 1383/2003 of 22 July 2003 concerning customs action against goods suspected of infringing certain intellectual property rights and the measures to be taken against goods found to have infringed such rights must be interpreted as meaning that:

goods coming from a non-member State which are imitations of goods protected in the European Union by a trade mark right or copies of goods protected in the European Union by copyright, a related right or a design cannot be classified as 'counterfeit goods' or 'pirated goods' within the meaning of those regulations merely on the basis of the fact that they are brought into the customs territory of the European Union under a suspensive procedure;

- $\quad$ those goods may, on the other hand, infringe the right in question and therefore be classified as 'counterfeit goods' or 'pirated goods' where it is proven that they are intended to be put on sale in the European Union, such proof being provided, inter alia, where it turns that the goods have been sold to a customer in the European Union or offered for sale or advertised to consumers in the European Union, or where it is apparent from documents or correspondence concerning the goods that their diversion to European Union consumers is envisaged;

- $\quad$ in order that the authority competent to take a substantive decision may profitably examine whether such proof and the other elements constituting an infringement of the intellectual property right relied upon exist, the customs authority to which an application for action is made must, as soon as there are indications before it giving grounds for suspecting that such an infringement exists, suspend the release of or detain those goods; and

those indications may include, inter alia, the fact that the destination of the goods is not declared whereas the suspensive procedure requested requires such a declaration, the lack of precise or reliable information as to the identity or address of the manufacturer or consignor of the goods, a lack of cooperation with the customs authorities or the discovery of documents or correspondence concerning the goods in question suggesting that there is liable to be a diversion of those goods to European Union consumers.

${ }^{29}$ Id. at II 62 . 
cooperate with authorities. ${ }^{30}$ Final proof of a substantive EU IP violation will in turn depend on firm, documented evidence of actual or planned diversion. ${ }^{31}$ This judgment by the Court should constitute a death knell for the "manufacturing" or "production" fiction that was used to justify seizure and diversion of generic medicines in transit. ${ }^{32}$

\section{CRITIQUe OF THE PROPOSED Border REGUlATION - BetTER IS NOT GOOD ENOUGH}

This is not the time to rehash the comprehensive critique of BMR 1383/2003, but rather to assess whether the Proposed Border Regulation ameliorates its harsh and unwarranted application of customs detention to in-transit generic medicines. Although the Proposed Border Regulation improves due process to deter patent holders' abuse of border measures, ${ }^{33}$ recognizes the Doha Declaration, ${ }^{34}$ and requires prompt court action

${ }^{30} I d$. at III $59,60$.

${ }^{31} I d$. at IIII 68,71 .

${ }^{32}$ See at $9 / 69$.

${ }^{33}$ See Proposed Border Regulation, supra note 6. New due process protections include: right holder liability to declarants or the holder of the goods for wrongful applications where the goods are determined not to be IP-infringing, but only if domestic law so provides (Art. 26); reimbursement to the state for costs of destruction (Art. 27); time limits on detentions pending decision on an application (Arts. $10 \& 11$ ); and goods holder (alleged infringer) right to be heard (Arts. 16, 17 \& 24). See generally Recital No. 15:

For further legal clarity and in order to protect the interests of legitimate traders from possible abuse of the border enforcement provisions, it is appropriate to modify the timelines for detaining goods suspected of infringing an intellectual property right, the conditions in which information about consignments is to be passed on to right-holders by customs authorities, the conditions for applying the procedure allowing for destruction of the goods under customs control for suspected infringements of intellectual property rights other than for counterfeit and pirated goods and to introduce a provision allowing the holder of the goods to express his/her views before the customs administration takes a decision which would adversely affect him/her.

Collectively these procedural protections, though improvements, do not totally ameliorate the risk of abusive applications for detention of goods nor remedy the harm not only to declarants and holders of the goods but also to purchasers of essential lifesaving medicines and their ultimate consumers who may suffer adverse health effects because of the interception of legitimate in-transit medicines.

${ }^{34}$ Proposed Border Regulation, supra note 6 at Recital No. 17:

Under the "Declaration on the TRIPS Agreement and Public Health" adopted by the Doha WTO Ministerial Conference on 14 November 2001, the TRIPS Agreement can and should be interpreted and implemented in a manner supportive of WTO Members' right to protect public health and, in particular, to promote 
regarding detentions based on suspected patent violations, ${ }^{35}$ the proposal still contains disruptive measures. These measures unjustifiably interfere with the legitimate trade of generic medicines of assured quality, and cause harm to vendors and shippers of the goods and to their purchasers and consumers. It contains these negative features despite the efforts of leading NGOs and commentators urging more extensive reforms that would have eliminated the risks of patent-based and civil-trademark-based seizures of generic medicines in transit. ${ }^{36}$

Problems with the Proposed Border Regulation include:

1. The proposed regulation continues coverage of patents, supplementary protection certificates for medicinal products (patent extensions), design rights, and civil trademark infringements, and thus continues to threaten access to medicines. ${ }^{37}$

In fact, the proposal extends border measures to entirely new intellectual property rights, including trade names, topographies of semiconductor products, utility models, and devices to circumvent technological measures, as well as any exclusive intellectual

access to medicines for all. ..."

It is important to note that this recital is preambular and imposes no direct obligation on an EU Member State.

${ }^{35}$ Id. at Recital 11; Art. 20.

Where goods suspected of infringing intellectual property rights are no counterfeit or pirated goods, it may be difficult to determine upon mere visual examination by customs authorities whether an intellectual property right might be infringed. It is therefore appropriate to provide that proceedings should be initiated, unless the parties concerned, namely the holder of the goods and the right-holder, agree to abandon the goods for destruction. It should be for the competent authorities dealing with such proceedings to determine whether an intellectual property right has been infringed and to take appropriate decisions concerning the infringements of intellectual property rights concerned.

${ }^{36}$ See, e.g., Thomas Jaeger, Henning Grosse Ruse-Khan, Josef Drexl \& Reto M. Hilty, Statement of the Max Planck institute for Intellectual Property, Competition and Tax Law on the Review of EU Legislation on Customs Enforcement of Intellectual Property Rights (2010), available at http://papers.ssrn.com/sol3/papers.cfm?abstract_id=1622619; Letter from Public Citizen to European Commission (May 25, 2010), available at http://www.citizen.org/documents/Public\%20Citizen\%20comments\%20submitted\%20to\% 20DG\%20TAXUD\%20on\%201383.pdf; Oxfam International, Public Consultation on the Review of Council Regulation 1383/2003 (2010), available at http://circa.europa.eu/Public/irc/taxud/consultation_ipr/library?l=/registered_organisations/ stichting_international/_EN_1.0_\&a=d. Most civil society comments focused primarily on the desirability of excluding patent rights from any revision of BMR 1383/2003.

${ }^{37}$ Proposed Border Measure, supra note 6, Art. 2(1)(e) \& (f). 
property rights established by Union legislation in the future. ${ }^{38}$ Instead of continuing to cover patents, supplementary protection certificates and expanding coverage to include utility models, civil trademark rights, and design rights, the scope of the Proposed Border Regulation should be restricted to criminal trademark counterfeiting and copyright piracy as defined by Articles 61 and 51 footnotes 14(a) and (b) of the TRIPS Agreement. ${ }^{39}$ Coverage of patents, supplementary protection certificates, utility models, design rights, and civil trademark rights should be explicitly excluded. By adopting such a limited, scope, the Proposed Border Regulation would prevent seizures of generic medicines because of weak, invalid or non-existent patent or utility model claims or because confusing similarity in trade name, trademark, or trade dress. ${ }^{40}$ Moreover, it would leave ordinary commercial disputes involving complex facts and IP rules to judicial resolution in the country of

${ }^{38}$ Id. Recital 5; Art. 2(1)(j)-(m).

${ }^{39}$ TRIPS, supra note 2019 , Article 51 n. 14 reads:

For the purposes of this Agreement:

(a) "counterfeit trademark goods" shall mean any goods, including packaging, bearing without authorization a trademark which is identical to the trademark validly registered in respect of such goods, or which cannot be distinguished in its essential aspects from such a trademark, and which thereby infringes the rights of the owner of the trademark in question under the law of the country of importation (emphasis added);

(b) "pirated copyright goods" shall mean any goods which are copies made without the consent of the right holder or person duly authorized by the right holder in the country of production and which are made directly or indirectly from an article where the making of that copy would have constituted an infringement of a copyright or a related right under the law of the country of importation.

TRIPS Article 61, in relevant part reads:

Members shall provide for criminal procedures and penalties to be applied at least in cases of willful trademark counterfeiting or copyright piracy on a commercial scale. Remedies available shall include imprisonment and/or monetary fines sufficient to provide a deterrent, consistently with the level of penalties applied for crimes of a corresponding gravity. In appropriate cases, remedies available shall also include the seizure, forfeiture and destruction of the infringing goods and of any materials and implements the predominant use of which has been in the commission of the offence. (Emphasis added.)

${ }^{40}$ Some health officials are now arguing that it may be desirable to encourage generic equivalents to have the same appearance or trade (size, shape, and color of the medicine) so as to promote generic substitution and reduce prescription errors by pharmacists, to avoid patient confusion, and to enhance patient adherence. Jeremy A. Greene \& Aaron S. Kesselheim, Why Do the Same Drugs Look Different? Pills, Trade Dress, and Public Health, 365 NEW ENGL. J. MED. 83-89 (2011). 
importation pursuant to the governing laws of that country as required by TRIPS.

\section{The Proposed Border Regulation continues to authorize application of the law of the transit country and the use of the manufacturing fiction, both of which inappropriately permit the seizure of generic medicines in transit.}

Under the Proposed Border Regulation, the definition of "goods suspected of infringing an intellectual property right" means "goods with regard to which there is adequate evidence to satisfy customs authorities that, in the Member State the goods are prima facie: goods which are subject to an action infringing an intellectual property right under the law of the Union or of that Member State (emphasis added)." ${ }^{, 41}$ More precisely, the applicable law used to determine whether "the use of ... goods gives rise to suspicion of infringement of an intellectual property right or has infringed an intellectual property right" is that of "the law [of the] Member State where the goods are found" (emphases added). ${ }^{42}$ This formulation is slightly different than the formulation of Recital No. 8 of BMR $1383 / 2003$ which stated that "[p]roceedings initiated to determine whether an intellectual property right has been infringed under national law will be conducted with reference to the criteria used to establish whether goods produced in that Member State infringe intellectual property rights (emphasis added)." The use of the phrase "use of those goods" versus "goods produced" would not seem to directly undermine the continuing viability of the manufacturing fiction under national law. For example, Article 28 of the TRIPS Agreement covers both "manufacturing" (production) and "use." Moreover, the Proposed Border Regulation is clear that

${ }^{41}$ Proposed Border Measure, supra note 6, Art. 2(7)(a). Although this language is somewhat confusing, its main import is that the law of individual EU Member States will continue to apply.

${ }^{42}$ Id. Art. 3

Applicable Law: ... the law of the Member State where the goods are found in one of the situations referred to in Article 1(1) shall apply for the purpose of determining whether the use of those goods gives rise to suspicion of infringement of an intellectual property right or has infringed an intellectual property right (emphasis added).

43 TRIPS, supra note $21 \underline{19}$ :

A patent shall confer on its owner the following exclusive rights: (a) where the subject matter of a patent is a product, to prevent third parties not having the owner's consent from the acts of: making, using, offering for sale, selling, or importing for 
it is not intended to affect in any way the laws of Member States. ${ }^{44}$ Accordingly, if a country maintains the manufacturing fiction with respect to assessing the patent or supplementary protection status of a medicine, as the Netherlands and other European countries clearly do, ${ }^{45}$ then an in-transit generic medicine could still be seized, adjudicated as an infringement, and thus destroyed, even if it was lawfully produced in the country of manufacture and destined for legal use in the final country of import. This fictive, non-territorial application of domestic law to transit goods is in direct violation of Articles $52^{46}$ and 51, footnote $14^{47}$ of the TRIPS Agreement, which requires application of "the law of the importing country" when assessing whether an intellectual property right at the border is violated or whether a good is a trademark counterfeit. There is no justification for applying fictive domestic IP law to goods that are not "used" so as to violate IP rights within the territorial market of the transit country. Applying such fictive rights, in essence becomes an extra-territorial application of purely domestic IP law and IP status to goods that are destined for commercialization or other use within that territory. To apply such fictive territorial rules could disrupt broad swathes of international trade using the most efficient trade routes as permitted by GATT. Dangerously, there is no reason that such fictive territoriality could not be extended with respect to other territorial regimes including labor rights, environmental rights, packaging/disclosure requirements, licensure, etc. Finally, any continued use of the manufacturing fiction should now be decisively illegal pursuant to the recent judgment of the European Court of Justice. $^{48}$

these purposes that product; (b) where the subject matter of a patent is a process, to prevent third parties not having the owner's consent from the act of using the process, and from the acts of: using, offering for sale, selling, or importing for these purposes at least the product obtained directly by that process.

${ }^{44}$ Proposed Border Measure, supra note 6, Art. 1.3.

${ }^{45}$ Olivier Vrins, The Real Story of a Fiction: Transit after Montex under Regulation (EC) 1383/2003, 5 J. InTEllectual L. \& PraC. 358, 358-371 (2010).

46 TRIPS, supra note 19, Art. 52: "Any right holder initiating the procedures under Article 51 shall be required to provide adequate evidence to satisfy the competent authorities that, under the laws of the country of importation, there is prima facie an infringement of the right holder's intellectual property right ...."

${ }^{47}$ See supra note 37.

${ }^{48}$ See supra notes 27-33. 
3. The exhortation for customs authorities to acknowledge transshipment as occurring within the context of international trade, and to "take account of any substantial likelihood of diversion [of medicines] onto the market of the Union," $" 49$ has no teeth and has no meaningful definition of how the likelihood of diversion is to be established.

Although Recital 17 says that customs authorities "should" take into account any substantial likelihood of diversion, it does not require them to do so. Likewise, although the actuality of imminent diversion into the European market is the only legally permissible basis upon which to base the territorial application of European IP status for a particular product, there is no guidance on what level or type of evidence of diversion would suffice. Mere suspicion of diversion should clearly be insufficient, but should there instead be evidence of planned purchase and distribution by an identified entity within the domestic market? Would it be sufficient to show a past practice of diversion by the manufacturer or distributor of the same good in the recent past? All of these questions need to be directly addressed and clarified at the very least by adopting explicitly the framework adopted by the European Court of Justice. ${ }^{50}$ Even the Court of Justice's ruling is undesirably weak with respect to authorizing temporary detention pending final adjudication of planned diversion directed at EU consumers. Accordingly, the proposed "evidence of diversion" provision justifying even temporary detention would be substantially strengthened if it were incorporated into the actual text of the regulation itself and if it were to say: "There may be no determination of prima facie suspicion of or violation of a covered intellectual property right in the absence of compelling evidence showing a substantial likelihood of imminent diversion of the challenged goods by an identified party onto the market of the European Union."

\footnotetext{
${ }^{49}$ Proposed Border Measure, supra note 6, Recital 17.

In particular with regard to medicines the passage of which across this territory of the European Union, with or without transshipment, warehousing, breaking bulk, or changes in the mode or means of transport, is only a portion of a complete journey beginning and terminating beyond the territory of the Union, customs authorities should, when assessing a risk of infringement of intellectual property rights, take account of any substantial likelihood of diversion of these goods onto the market of the Union.

${ }^{50}$ See supra notes 27-33.
} 
4. The time period for declarants or the holder of goods to respond to detention of suspect goods is too short.

Temporary suspension of the release of goods or their detention can be pursued ex parte either by an application of the right-holder or other identified surrogate using Articles 4-6 or by unilateral ex officio action of customs authorities, who thereafter must request the right holder to initiate an application, Article 17. In either event, customs authorities are required to communicate their intentions to the declarant or, in the case of detention, the holder of the goods after the fact, and only then is the declarant or holder "given the opportunity to express his/her views within three working days." Upon granting an application, the competent customs department must suspend the release of the goods or detain them and must promptly notify both the holder of the decision (the right holder) and the declarant or holder of the goods of its decision. ${ }^{52}$ Although these notice and opportunity to be heard provisions are an improvement over BMR 1383/2003, the three-day time period granted to declarants and holders of the goods is insufficient to give them fair opportunity to amass evidence concerning the lawful IP status of the goods in issue and to confirm the ultimate destination of in-transit goods outside the EU. Declarants and holders of goods should be given at least 10 days for such a showing and there should be additional provisions allowing for a further extension upon proper motivation.

5. Even temporary detention of generic medicines adversely affects the rights of intended purchasers and users and the Proposed Border Regulation leaves them without a remedy.

A further requirement applying to non-counterfeit or pirated goods (criminal trademark and copyright violations) - namely goods alleged to have infringed design, patent, supplementary protection certificates, utility model, or plant variety rights - is that they must initiate proceedings for a court decision determining that the IP right in question has been violated. ${ }^{53}$ However, the requirement of additional court proceedings does not prevent pre-determination seizure either upon application of the right-holder or even ex officio

${ }^{51} I d$. at Arts. $16.3 \&$ 17.3. A longer time period of 20 days is granted when customs officials propose to destroy goods in small consignments. Art. 24.4.

${ }^{52}$ Id. at Arts. 16.4, 17.4.

${ }^{53}$ Id. at Art. 20.1. 
by the customs authority. Admittedly, the goods will be detained, pursuant to a granted application, for only a limited period of time 10 days - unless proceedings are promptly initiated, but goods thereafter can ordinarily be detained until the court proceedings have ended, a time period that can last months or even years. ${ }^{54}$ There are procedures for release of goods upon payment of adequate security, and there are eventual remedies for applications and proceedings where it is determined that IP rights have not been violated, but these partial remedies do not always compensate holders of the goods for lost commercial opportunities and disruptions of their business, nor do they provide remedies for intended purchasers and ultimate consumers whose needs for life-saving and healthenhancing medicines have been frustrated. Buyers, including government purchasers might have to use special and higher cost procurement methods to get emergency supplies. If they are fiscally unable to do so, or if suppliers cannot meet their needs immediately because of orders from other customers, public health programs and the immediate medical needs of patients might not be met. At present, there are no remedies for such purchasers or consumers, nor even are there confirmed remedies for declarants or holders of goods unless, and only to the extent that, the law of the country in question so provides. ${ }^{55}$ The Proposed Border Regulation should be amended to provide much more certain and robust remedies for declarants and holders of goods and for purchasers and customers who may have suffered harm as a proximate result of right-holders' unsuccessful actions under the regulation.

\footnotetext{
${ }^{54}$ This ten-day period can be extended another ten days upon application except in the case of perishable goods. Id. at Art. 20.4. There are provisions for the declarant or holder of the goods to seek their release from detention, but only if adequate security has been posted, no precautionary measures (preliminary injunctions) have been entered, and all customs formalities completed; Art. 21.1.

${ }^{55}$ Id. at Art. 26:

Where a procedure duly initiated pursuant to this Regulation is discontinued owing to an act or omission on the part of the holder of the decision granting the application or where the goods in question are subsequently found not to infringe an intellectual property right, the holder of the decision granting the application shall be liable towards the persons involved in a situation referred to in Article 1(1) in accordance with the legislation of the Member State where the goods were found.
} 


\section{CONCLUSION}

A better regulation would have excluded coverage of patents, supplementary protection certificates, utility models, design rights, and civil trademark violations and/or specifically prevented application of a domestic manufacturing or use fiction with respect to in-transit goods. It would have much more directly addressed the Doha Declaration and clarified that no customs action should be undertaken with respect to in-transit generic medicines lawfully produced in the country of origin and lawfully imported into the country of use, unless there is concrete and compelling evidence of imminent diversion of the goods into the European market by an identified party. Declarants and holders of goods should be given more meaningful opportunities to object to detention and seizure of their goods and to oppose applications by right holders. And, the provisions for remedies when right holders' applications are unsuccessful should be expanded both for declarants/holders-of-goods and ultimate purchasers/consumers whose interests have been proximately harmed by the wrongful detention and/or destruction of goods.

Instead, the EC has attempted to strengthen the enforcement rights of IP right holders and has once again passed the buck to country-specific IP legislative standards and enforcement criteria. These country specific standards and criteria, including the manufacturing/domestic-use fiction, may once again run afoul of fundamental precepts of intellectual property law, the TRIPS Agreement and GATT, and public health needs enshrined in the Doha Declaration and in other binding human rights instruments. Europe has treated its reform obligations primarily as an exercise in balancing expanded intellectual property protections against greater due process rights, without addressing the most fundamental defects in the BMR $1383 / 2003$ regime, a defect that has also been identified by the European Court of Justice. Accordingly, European parliamentarians should reject the Proposed Border Regulation in its current form as should India and Brazil with respect to their suspended WTO complaints. 